\title{
HUBUNGAN PENGETAHUAN IBU POST PARTUM DENGAN PEMBERIAN KOLOSTRUM DIRUANG PNC RSUD SALEWANGANG KABUPATEN MAROS
}

\author{
St. Rahmawati Hamzah \\ Program Studi DIII Kebidanan, STIKES Graha Medika, JL. Raya AKD RSI Monow, Mongkonai Barat Kota \\ Kotamobagu, rahmahamzah94@gmail.com
}

Diterima 16 Januari 2020, disetujui 16 April 2020, diterbitkan 30 April 2020

Pengutipan: Hamzah, S. R. (2020). Hubungan Pengetahuan Ibu Post Partum dengan Pemberian Kolostrum di Ruang PNC RSUD Salewangang Kabupaten Maros. Gema Wiralodra, Vol 11, No 1, Hal 124132, April 2020

\begin{abstract}
ABSTRAK
Latar Belakang penelitian ini dilaksanakan karena dari hasil survey awal yang dilakukan peneliti kepada 8 orang pasien post partum di ruang PNC RSUD Salewangang Maros, dimana 3 orang ibu memberikan kolostrumnya pada hari pertama setelah melahirkan dan 5 orang lainnya tidak memberikan ASI kolostrum disebabkan kurangnya informasi dari petugas kesehatan dan adanya pemahaman ditengah-tengah masyarakat bahwa ASI kolostrum merupakan ASI yang basi dan tidak perlu untuk diberikan pada bayi baru lahir. Dalam hal ini ibu yang memiliki pengetahuan yang baik tentang ASI kolostrum ia tidak akan membuang ASI yang pertama kali keluar setelah persalinan dan memberikan ASI kolostrum pada bayinya. Variabel yang terlibat dalam penelitian ini adalah variabel independen yaitu pengetahuan ibu post partum dan variabel dependen yakni pemberian kolostrum. Metode penelitian ini adalah analitik kuantitatif dengan pendekatan cross sectional study. Sampel diambil secara purposive Sampling dengan jumlah sampel ibu post partum sebanyak 30 responden. Analisis data adalah Univariat dan Bivariat yang di analisis menggunakan program SPSS 16. Hasil pengujian keterkaitan antar kedua variabel ini melalui uji Chi-Square, dimana diperoleh nilai signifikan $\mathrm{p}=0,000<\alpha=0,05$, ini berarti Ho ditolak dan Ha diterima. Kesimpulan dari penelitian ini adalah ada hubungan pengetahuan ibu post partum dengan pemberian kolostrum di ruang PNC RSUD Salewangang maros. Saran bagi para peneliti Selanjutnya agar dapat dijadikan masukan khususnya mengenai pengetahuan tentang ASI kolostrum., agar pengetahuan yang di miliki dapat terus bertambah.

Kata Kunci : Pengetahuan, Pemberian Kolostrum
\end{abstract}

\begin{abstract}
This observational background executed because of survey's result first few that done by researcher to 8 patients post partum at spatial PNC RSUD Salewangang Maros, where 3 mothers gives kolostrumnya on day one of afters bears and 5 another persons don't give kolostrum's Attentions caused by its reducing informations of health officer and grasp mark sense to be intermediated that society kolostrum's Attention constitute stale Attention and not necessarily to been given on newborn baby. in this case mother which have good science about Attention kolostrum it won't discard Attention that afterses outward first time about copy and give kolostrum's Attention on its baby. Variable one that is mixed up in this research is independent variable which is mother science post partum and dependen's variable namely kolostrum's application. This observational method is analytic quantitative with approaching cross sectional study . Sample was taken by ala purposive is Sampling with mother sample amount post partum as much 30 respondents. Analisis is data is Univariat and Bivariate that at analisis utilizes to program SPSS 16.0. Relevance examination result among variable second through quiz this Chi
\end{abstract}

Diterbitkan oleh:

Universitas Wiralodra

Jln. Ir. H. Juanda Km 3 Indramayu, Jawa Barat 
Square, where gotten by signifikan's point $\mathrm{p}=0.000<\alpha=0.05$, this matter Ho is refused and Ha is accepted. Conclusion of this research is available mother gnostic relationship post partum with kolostrum's application at spatial PNC RSUD Salewangang Maros. Tips for researchers succeeding to be able to been made entry in particular about science about Attention kolostrum., that proprietary science gets continually crescent

Keywords: Science, Kolostrum's application

\section{PENDAHULUAN}

Masalah pemberian Air Susu Ibu (ASI) kepada bayi patut menjadi perhatian serius pemerintah dan masyarakat, mengingat bahwa ASI sangat penting bagi bayi. WHO (world health organization) merekomendasikan semua bayi perlu mendapatlkan kolostrum (ASI hari pertama sampai ketiga) untuk melawan infeksi dan mendapat ASI Ekslusif 6 bulan untuk menjamin kecukupan gizi bayi. Rekomendasi ini dikeluarkan mengingat bahwa data WHO menunjukkan ada 170 juta anak mengalami gizi kurang diseluruh dunia dan sebanyak 3 juta diantaranya meninggal setiap tahun karena gizi buruk dalam hal ini jika ASI yang diberikan sebagai sumber asupan satu-satunya bagi bayi usia 0-6 bulan (Nuryanti, 2009).

UNICEF (United Nations International Children's Emergency Fund) dan WHO merekomendasikan para ibu-ibu untuk menyusui secara eksklusif selama 6 bulan kepada bayinya. ASI merupakan sumber gizi yang sangat ideal dan seimbang yang diperlukan oleh bayi terutama pada bulan pertama kehidupan (Turyati \& Nurbaeti, 2018). Setelah usia 6 bulan, baru bayi dapat diberikan makanan pendamping ASI (MPASI), dengan tetap memberikan ASI sampai anak berusia minimal 2 tahun. Riskesdas tahun 2010 merupakan kegiatan riset kesehatan yang berbasis pada masyarakat, yang diarahkan untuk mengevaluasi hasil pencapaian indikator MDGs (Millenium Development Goals) di bidang kesehatan ditingkat nasional/propinsi. Berdasarkan hasil Riskesdas tahun 2010 dan Riskesdas Tahun 2013, menyajikan kecenderungan pemberian kolustrum dimana sebagian besar responden menjawab kolostrum diberikan semua atau tidak dibuang (Kemenkes RI, 2013).

Kolostrum adalah cairan berwarna kuning kental dan mengandung zat kekebalan tubuh (antibodi). Biasanya, kolostrum sudah diproduksi pada tahap akhir kehamilan sehingga sudah ada segera setelah melahirkan sampai hari ke-4 kelahiran. Kolostrum kaya 
akan sel imunitas (kekebalan) tubuh, antibody dan protektif lainnya. Jadi kolostrum memberikan "imunisasi pertama” melindungi terhadap infeksi (Adiningrum, 2014).

Persentase IMD tertinggi di Provinsi Nusa Tenggara Barat (NTB) sebesar 52,9\%, sedangkan terendah di Provinsi Papua Barat sebesar 21,7\%. Cakupan IMD Nasional sebesar 34,5\% dan terdapat 18 Provinsi yang cakupannya dibawah angka nasional. Perlu dilakukan upaya agar ke-18 provinsi tersebut dapat meningkatkan nilai cakupannya, salah satunya dengan cara melakukan penyuluhan oleh bidan dan tenaga kesehatan lainnya (Kemenkes RI, 2013).

Faktor yang diketahui berpengaruh terhadap pemberian ASI kolostrum pada anak baru lahir adalah pengetahuan (Akbar, 2017). Penelitian yang dilakukan di Puskesmas Ulu Kabupaten Kepulauan Sitaro dengan jumlah sampel sebanyak 20 orang ibu nifas, menemukan ada hubungan pengetahuan ibu nifas tentang pemberian kolostrum pada bayi baru lahir, melalui pengujian data dihasilkan nilai $\mathrm{P}=0,000$ pada level 0,01 (Papona, Laoh, Palendeng, 2013). Penelitian di BPS Aida Hartatik Lamongan dengan jumlah sampel sebanyak 21 responden, didapatkan data 21 responden $(75,0 \%)$ responden yang memberikan kolostrum pada bayinya dan ibu rata-rata yang berpengetahuan baik 20 responden $(71,4 \%)$ kemudian dilakukan uji statistik didapatkan nilai $\mathrm{p}<0,05$ hasilnya Ho ditolak yakni ada hubungan pengetahuan pada ibu post partum tentang manfaat kolostrum dengan pemberian kolostrum pada bayi baru lahir (Nasihah dan Sari, 2015).

Dari data yang diambil di RSUD Salewangang Maros menunjukkan pada tahun 2014 jumlah pasien yang melahirkan sebanyak 820 orang. Pada tahun 2015 pasien yang melahirkan sebanyak 753 orang. Dan dari hasil survey awal yang dilakukan peneliti kepada 8 orang pasien post partum di ruang PNC RSUD Salewangang Maros, dimana 3 orang ibu memberikan kolostrumnya pada hari pertama setelah melahirkan dan 5 orang lainnya tidak memberikan ASI kolostrumnya pada hari pertama setelah melahirkan, diperoleh data 1 orang ibu nifas berpengetahuan baik tetapi tidak memberikan kolostrum kerena puting susunya tenggelam dengan alasan ASI belum keluar, kemudian 2 orang ibu nifas berpengetahuan cukup dan 2 orang ibu nifas yang berpengetahuan kurang tidak memberikan kolostrum dengan alasan karena setelah proses persalinan selesai ibu merasa lemas dan tidak bisa menyusui bayinya dan kurangnya pengetahuan tentang ASI kolostrum

Diterbitkan oleh:

Universitas Wiralodra

Jln. Ir. H. Juanda Km 3 Indramayu, Jawa Barat 
(RSUD Salewangang Maros, 2016). Tujuan penelitian ini yaitu diketahuinya Hubungan Pengetahuan Ibu Post Partum dengan Pemberian Kolostrum di ruang PNC RSUD Salewangang Kabupaten Maros.

\section{METODE PENELITIAN}

Jenis penelitian ini adalah observasional analitik dengan pendekatan Cross sectional Study. Populasi dalam penelitian ini adalah semua ibu post partum hari ke 1-4 yang dirawat diruang PNC RSUD Salewangang Kabupaten Maros saat dilakukan penelitian sedangkan sampel adalah sebagian dari populasi. Besar sampel dalam penelitian sebanyak 30 responden. Pengambilan sampel menggunakan teknik purposive Sampling. Pengumpulan data diperoleh dari data primer dengan menggunakan kuesioner dan data sekunder yang didapatkan dari data rekam medik di RSUD Salewangan Kabupaten Maros pada tahun 2018. Data dianalisis secara univariat dan bivariate dengan menggunakan uji Chi Square.

\section{HASIL DAN PEMBAHASAN}

\section{Hasil}

Tabel 1. Distribusi Frekuensi Berdasarkan Karakteristik Responden diruang PNC RSUD Salewangang Kabupaten Maros

\begin{tabular}{ccc}
\hline Umur (Tahun) & N & \% \\
\hline $20-35$ & 27 & 90 \\
\hline$<20$ dan $>35$ & 3 & 10 \\
\hline Pendidikan & $\mathbf{N}$ & $\mathbf{\%}$ \\
\hline Tinggi & 17 & 43,3 \\
\hline Rendah & 13 & 56,6 \\
\hline Pekerjaan & $\mathbf{N}$ & $\mathbf{\%}$ \\
\hline Bekerja & 8 & 26,7 \\
\hline Tidak Bekerja & 22 & 73,3 \\
\hline Jumlah & $\mathbf{3 0}$ & $\mathbf{1 0 0}$
\end{tabular}

Tabel 1 di atas menunjukkan umur responden paling banyak umur 20 - 35 tahun sebanyak 27 (90\%), dan yang paling rendah adalah umur $<20$ dan $>35$ tahun sebanyak 
3 (10\%). Responden yang berpendidikan tinggi sebanyak 17 (43,3\%), sedangkan yang berpendidikan rendah sebanyak 13 responden (56,6\%). Responden yang tidak bekerja sebanyak $8(26,7 \%)$ dan yang bekerja sebanyak 22 responden $73,3 \%$.

Tabel 2. Analisis Univariat

\begin{tabular}{ccc}
\hline Pengetahuan & N & \% \\
\hline Baik & 16 & 53,3 \\
\hline Kurang & 14 & 46,7 \\
\hline Pemberian kolostrum & $\mathbf{N}$ & $\mathbf{\%}$ \\
\hline ASI Kolostrum & 20 & 66,7 \\
\hline Bukan ASI Kolostrum & 10 & 33,3 \\
\hline Jumlah & $\mathbf{3 0}$ & $\mathbf{1 0 0}$ \\
\hline
\end{tabular}

Tabel 2 di atas menunjukkan jumlah responden yang mempunyai pengetahuan baik sebanyak 16 (53,3\%), dan yang kurang sebanyak 14 (46,7\%). Responden yang memberikan ASI kolostrum sebanyak $20(66,7 \%)$ dan yang bukan ASI kolostrum sebanyak $10(33,3)$.

Tabel 3. Analisis Bivariat

\begin{tabular}{|c|c|c|c|c|c|c|c|}
\hline \multirow{3}{*}{ Pengetahuan } & \multicolumn{4}{|c|}{ Pemberian Kolostrum } & \multirow{2}{*}{\multicolumn{2}{|c|}{ Total }} & \multirow[b]{2}{*}{$\begin{array}{c}\text { p-value } \\
\left(\mathrm{X}^{2}\right)\end{array}$} \\
\hline & \multicolumn{2}{|c|}{$\begin{array}{c}\text { ASI } \\
\text { Kolostrum }\end{array}$} & \multicolumn{2}{|c|}{$\begin{array}{l}\text { Bukan ASI } \\
\text { Kolostrum }\end{array}$} & & & \\
\hline & $\mathrm{n}$ & $\%$ & $\mathrm{n}$ & $\%$ & $\mathrm{~N}$ & $\%$ & \\
\hline Baik & 16 & 100 & 0 & 0 & 16 & 100 & 0,000 \\
\hline Kurang & 4 & 28,6 & 10 & 71,4 & 14 & 100 & \\
\hline Total & 20 & 66,7 & $\mathbf{1 0}$ & 33,3 & 30 & 100 & \\
\hline
\end{tabular}

Tabel 3 di atas menunjukkan dari 16 responden yang mempunyai pengetahuan baik terdapat $16(100 \%)$ reseponden yang memberikan ASI kolostrum, sedangkan dari 14 responden yang mempunyai pengetahuan yang kurang terdapat $10(71,4 \%)$ yang tidak memberikan ASI kolostrum dan sebanyak $4(28,6 \%)$ responden yang memberikan ASI kolostrum. 
Berdasarkan hasil uji Chi Square diperoleh nilai $\rho=0,000$ atau $(\rho<0,05)$. Maka Ho ditolak sehingga dapat disimpulkan ada hubungan Pengetahuan Ibu Post Partum dengan Pemberian Kolostrum diruang PNC RSUD Salewangan Kabupaten Maros.

\section{Pembahasan}

Pengetahuan adalah hasil dari "tahu" dan ini terjadi setelah orang melakukan penginderaan terhadap suatu objek tertentu. Penginderaan terjadi melalui panca indera manusia, yakni indera penglihatan, pendengaran, penciuman, rasa dan raba. Pengetahuan dapat membantu seseorang untuk mengembangkan cakrawala berpikir sehingga dengan demikian mudah baginya untuk melakukan sesuatu tergantung pada pengetahuan yang ia miliki. Dengan adanya pengetahuan, akan membawa seseorang untuk memahami dan sekaligus menerapkan apa yang ia ketahui tersebut dalam kehidupan sehari-hari (Notoatmodjo, 2010).

Hasil penelitian didapatkan dari 16 responden yang mempunyai pengetahuan baik terdapat $16(100 \%)$ reseponden yang memberikan ASI kolostrum, sedangkan dari 14 responden yang mempunyai pengetahuan yang kurang terdapat $10(71,4 \%)$ yang tidak memberikan ASI kolostrum.

Berdasarkan uji Chi-Square, diperoleh nilai signifikan $\mathrm{p}=0,000<\alpha=0,05$, ini berarti Ho ditolak dan Ha diterima. Dapat disimpulkan bahwa ada hubungan pengetahuan ibu post partum dengan pemberian kolostrum diruang PNC RSUD Salewangang Kabupaten Maros.

Hasil penelitian ini sejalan yang dilakukan di Ruang Kamar I RSUD Arifin Achmad Riu dengan jumlah sampel sebanyak 170 responden, menemukan ada hubungan pengetahuan dengan pemberian kolostrum adalah p-value 0.044 (Maita dan Shalihah, 2015). Penelitian lain yang dilakukan di Polindes Desa Karangwedo dengan jumlah sampel sebanyak 28 responden, menemukan ada hubungan pengetahuan ibu post partum tentang manfaat kolostrum dengan pemberian kolostrum pada bayi baru lahir p=0,000 (Kustini, 2018). Penelitian yang dilakukan di RB Kharisma Panjang Kota Bandar Lampung dengan jumlah sampel 50 ibu bersalin, menemukan ada hubungan yang signifikan antara pengetahuan ibu dengan pemberian ASI dini, dimana didapatkan nilai $\mathrm{p}$ Value $=0,000$ dan 
$\mathrm{OR}=144,0$ artinya ibu dengan pengetahuan kurang berpeluang 144 kali tidak memberikan kolostrum dibandingkan ibu yang yang berpengetahuan baik (Indrasari dan Ningsih, 2019)

Menurut pendapat peneliti bila dilihat dari hasil penelitian di atas, ibu yang berpengetahuan kurang yang tidak memberikan kolostrum disebabkan karena kurangnya pengetahuan ibu tentang kolostrum, sehingga ibu tidak memberikan kolostrum pada bayinya. Faktor lingkungan dan budaya responden bahwa kolostrum tidak baik diberikan pada bayinya. Ada beberapa responden mengatakan bahwa ASI yang pertama kali keluar bewarna kuning itu merupakan ASI basi. Selain itu dapat disebabkan karena ASI yang tidak keluar segera setelah melahirkan atau tidak lancar pada hari-hari pertama keluar sehingga ibu memberikan susu formula kepada bayinya (Sunesni dan Wahyuni, 2018).

Hasil penelitian diatas terdapat pula ibu yang berpengetahuan kurang namun tetap memberikan ASI kolostrumnya sebanyak 4 orang $(28,6 \%)$ karena ibu mendapat informasi yang lengkap dari petugas persalinan, pengetahuan ibu tentang kolostrum dipengaruhi oleh peran aktif petugas kesehatan seperti memberikan penyuluhan tentang kolostrum. Pengetahuan ibu tentang kolostrum yang dimaksud dalam penelitian ini yaitu segala sesuatu yang ibu ketahui tentang ASI kolostrum.

Salah satu manfaat ASI kolostrum adalah untuk meningkatkan kekebalan tubuh bayi, pemberian ASI kepada bayi harus tetap dilanjutkan ke ASI ekslusif. Jika bayi diberikan makanan tambahan selain ASI pada usia dibawah enam bulan akan meningkatkan risiko terkena berbagai macam penyakit misalnya diare. Hal ini terbukti pada penelitian yang dilakukan di wilayah kerja Puskesmas Juntinyuat, dengan jumlah sampel 69 responden, menemukan ada hubungan antara pemberian ASI eksklusifdengan kejadian diare pada balita di wilayah kerja Puskesmas Juntinyuat, dengan nilai $\mathrm{p}$ value $=0,001$ atau nilai $\mathrm{p}$ value $<0,05$. Hal ini berarti pemberian ASI eksklusif berhubungan dengan kejadian diare pada balita (Rahmawati, 2019).

\section{KESIMPULAN}


Berdasarkan hasil penelitian maka dapat disimpulkan ada hubungan pengetahuan responden dengan pemberian ASI kolostrum. Hasil penelitian ini bisa menjadi masukan kepada ibu nifas untuk meningkat pengetahuan tentang ASI kolostrum. Disarankan kepada ibu yang masih memiliki tingkat pengetahuan kurang mengenai ASI kolostrum agar kiranya lebih banyak mencari informasi dari petugas kesehatan atau mencari referensi tentang ASI kolostrum sehingga dapat memberikan nutrisi yang terbaik untuk sang buah hati setelah persalinan.

\section{UCAPAN TERIMAKASIH}

Peneliti mengucapkan terimakasih kepada Direktur RSUD Salewangan Kabupaten Maros dan Jajarannya serta kepada rekan-rekan dan keluarga yang telah membantu peneliti demi kelancaran pelaksanaan penelitian ini.

\section{DAFTAR PUSTAKA}

Adiningrum, H. (2014). Buku Pintar ASI Eksklusif. Jakarta Timur : Salsabila Pustaka Alkautsar Group.

Anggeni, U. (2018). Hubungan Pengetahuan Ibu Post Partum Dengan Pemberian Kolostrum Pada Bayi Baru Lahir Di BPM Choirul Mala, SKM, SST, M.Kes Palembang Tahun 2017. Jurnal Kesehatan dan Pembangunan, Vol. 8, No.16.

Akbar, H. (2017). Faktor yang Berhubungan dengan Kejadian Diare pada Anak Balita di Kecamatan Sindue Kabupaten Donggala. Jurnal Kesehatan Masyarakat, Vol 2, No 3, 78-83.

Indrasari, N \& Ningsih, R. (2012). Faktor - Faktor yang Berhubungan dengan Pemberian Kolostrum pada Ibu Post Partum. Jurnal Kesehatan Metro Sai Wawai Volume V No. 2 Edisi Desember 2019.

Kemenkes RI. (2013). Riset Kesehatan Dasar; RISKESDAS. Jakarta: Balitbang Kementrian Kesehatan RI.

Maita, Liva \& Shalihah, N. (2015). Faktor-Faktor Yang Menyebabkan Pemberian Kolostrum Pada Ibu Nifas di Ruang Camar I Rsud Arifin Achmad Provinsi Riau . Jurnal Maternity dan Neonatal Volume 1 No 6.

Notoatmojo, S. (2010). Promosi Kesehatan dan Ilmu Prilaku. Jakarta: Rineka Cipta Nuryanti, L. (2009). Masalah Pemberian Air Susu Ibu. Jurnal Kesehatan. (http:// Publikasi Ilmiah.ums.ac.id. diakses 25 januari 2016).

Diterbitkan oleh:

Universitas Wiralodra

Jln. Ir. H. Juanda Km 3 Indramayu, Jawa Barat 
Nasihah, M \& Sari, L.D.N. (2015). Hubungan pengetahuan ibu post partum tentang manfaat kolostrum dengan pemberian kolostrum pada bayi baru lahir di BPS. Aida Hartatik A.Md, Keb Ds. Dlanggu Kec. Deket Lamongan 2015. Midpro, Vol 7, No 2, Desember 2015.

Kustini. (2018). Hubungan Pengetahuan Ibu Post Partum tentang Manfaat Kolostrum dengan Pemberian Kolostrum pada Bayi Baru Lahir. Journal for Quality in Women's Health, Vol 1, No 2, September 2018.

Papona, N, Laoh, J \& Palandeng, H. (2013). Hubungan Pengetahuan dan Sikap Ibu Nifas tentang Pemberian Kolostrum pada Bayi Baru Lahir di Puskesmas Ulu Kecamatan Siau Timur Kabupaten Kepulauan Sitaro. Jurnal Keperawatan, Vol 1, No 1, Agustus 2013.

Rahmawati, Ade. (2019). Pemberian Asi Eksklusif dan Status Gizi Serta Hubunganya terhadap Kejadian Diare Pada Balita di Wilayah Kerja Puskesmas Juntinyuat. Gema Wiralodra, Vol 10, No 1, April 2019.

RSUD Salewangang Maros. (2015). Buku Register RSUD Salewangeng Maros. Kabupaten Maros, Sulawesi Selatan.

Sunesni \& Wahyuni, N.S. (2018). Hubungan Pengetahuan, Paritas dan Pendidikan Ibu dengan Perilaku Pemberian Kolostrum di Kelurahan Gunung Sarik Wilayah Kerja Puskesmas Belimbing, Tahun 2018. Jurnal Kesehatan Mercusuar, Vol. 1, No. 1, 2018).

Turyati, \& Nurbaeti, T. S. (2018). Faktor- Faktor yang Mempengaruhi Status Gizi Anak Balita Di Desa Loyang Wilayah Kerja Puskesmas Cikedung Kabupaten Indramayu Tahun 2018. Afiasi, Vol 3, No 3, 111-119.

Diterbitkan oleh: 